\title{
FOMC Policy Actions in 1972
}

\author{
by JERRY L. JORDAN
}

HE PRIMARY policy objective of the Federal Open Market Committee (FOMC) in early 1972 was to provide sufficient monetary growth to facilitate continued real economic expansion in an environment in which administrative controls on prices and wages had been imposed. Late in 1972 the directive of the Federal Open Market Committee specified slower growth of monetary aggregates as the policy discussions indicated an increasing concern for the possibilities of re-emergence of inflationary pressures. ${ }^{1}$

This review of policy actions of the FOMC in 1972 will include little reference to the "New Economic Program." No one, including members of the FOMC, would be able to say for certain how, or even whether, monetary policy decisions would have been different last year if underlying economic conditions had been the same but there had been no price-wage control program.

The primary source of information for this article is the "Record of Policy Actions" of the Federal Open Market Committee." These "Records" of policy ac" tions contain little reference to the Government's control program. Consequently, there is no explicit indication of the extent to which the various aspects of the Administration's program served as either a constraint on, or as an inducement to, FOMC actions.

\footnotetext{
tThe membership, procedures, and terms used in connection with the FOMC are discussed in the screened section entitled "The ifederal Open Market Committee in 1972."

¿Unless specificaly noted, all quotes in this article come from the "Record of Policy Actions" of the Federal Open Market Conmintes, released abont 90 days after each meeting and later published in the Federal Reserve Bulletin. Supplementary infomation regarding monetary and financial developments during the year is contained in quarterly reports prepared by the staff of the Board of Governors, and sent to the Joint Economic Committee of Congress. These reports are pablisted in the Federal Reserve Bulletin approximately every three months. They provide the views of the Boards state regarding novements in interest rates and monetary and reserve aggregates over the course of the prior quarter.
}

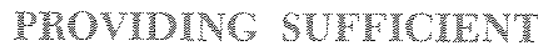

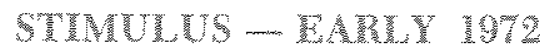

The "policy consensus" and "operating instructions" at the first meeting of 1972 were unchanged from the December 1971 meeting. ${ }^{3}$ In fact, the policy consensus in January 1972 was identical to that of the last five meetings in 1971, all following the August 15 announcement of the New Economic Program. Specifically, the policy of the FOMC was to "foster financial conditions consistent with the aims of the new govemmental program. ..." These aims were said to include "sustainable real economic growth and increased employment, abatement of inflationary pressures, and attainment of reasonable equilibrium in the country's balance of payments."

Although the actions necessary to achieve each of these goals would involve some conflict if pursued simultaneously and equally, the operating instructions provide some indication of the weight given by the Committee to these goals. In November 1971 the Committee's instructions had indicated a desire to "promote somewhat greater growth in monetary and credit aggregates," while at the December 1971 meeting this seems to have become a more definite objective as the Committee sought to "promote the degree of ease in bank reserve and money market conditions essential to greater growth in monetary aggregates. ..."4

"Throughout this article these terms refer, respectively, to the last two sentences in the directive. Sex Exhibit I for further reference to these terms.

In February 1973 the Federal Reserve Board released revised data for monetary aggregates for the previous fourteen years. However, unless specifically noted otherwise, throughout this article references to monetary and reserve aggregates are based on the former series - the data available to the Connittee at the time of their deliberations. Page 12 contains rates-of-change triangles for the money stock series on both the old and the revised basis. Also, all rates-of-change computations are on a compound annual basis unless contained within quoted material or specifically noted otherwise. 


\section{The Federal Open Market Committee in 1972}

The Federal Open Warket Committee 4 omc) consists of the seven menbers of the federal Reserve Bowd of Goverious and five of 1 lie lwelve Tederal Reserve Bank Yresidents. The Chamman of the Board of Govenuors is als, br tradition, Ohaimman of the

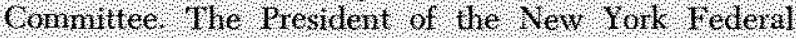
Reserve Bank is a petmanent voting nember of the Committee and, also by tradition, is its Vire Qhaminan. All other Tederal heserve 1 ank P estdents altend the meetings and present theit nievs, but toles nat be calt by only hour of hese Presillents, who serve as vol ing nembers for one-vear tem on a rofation basis.

Menbers of the Bowd of Grwemors for nost of

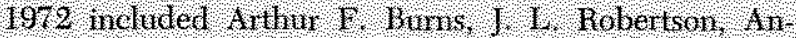

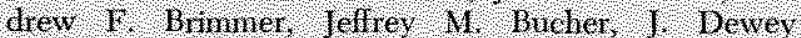
Dame, George W. Mitchell, and Tohn E. Sheehan The tern of Govennor. Sherman Mhisel expired on

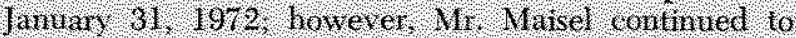
senve as 4 (oovernor and to valluppate in Federal Oper Market Commithe neetings hrough Aphl last year, Jelley M. Bheher Gined the Buard on Jure 5 last year te fill he posilion wated lov Mr. Maisel Mr. Bucher has parthipated in Whe. TOML heethas

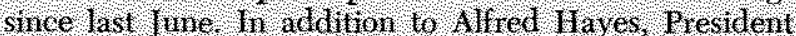
of the Tederat hesene Bank of New Mork, We follow. his Presidents serval on the Commitiee dirng lan-

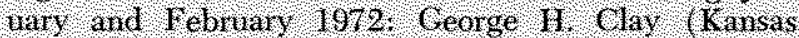
City), Monoe Kimbrel ( Mlanta) Robert P. Mayo (Clucage) and Trank $\mathrm{E}$. Mamis (Boston $)$ In March the Commillee was rearganized and the four rolating positions were fllled by lhe following new nembers:

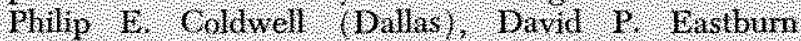
(Philadelpho), Brace $\mathrm{K}$, Macl Lany (Minneapolis) and Wills I Wimi (cleveland)

The Commillee reguilat net once eadh month during 1972 to discuss econonie trends and to dechde ipon the titume course of open narket operations. At Gese neetings they my discuss other possible policy actions for subseguent weeks and nonths. at each meeting, a directive was issued to the Federal Re. serve Bank of New Youl stating the ultmate goals of the Commilee and providing general guid lines as (6) how the Manager of the System Open Market Account ' at the New York Tederal Meservo Bank shond condict open maket operations to aeheve: these goals. Gach directive contanted a short revew of economie dala considered and the general economie godts sought by the Cemnittee The second paragraph grwe opelating instructions to the Aceount Wanager. The se instuncturs were stated in terms of bank te. serve and noney nurket conditons to aheve desired growth rates of nonetary aggregates, and any spectal factors 10 be laken into teeount, sueh as Theasury finutng operations.

The Manager of the System Open Market Lecount nay be telerred to as the Account Whater and the Trading Desk of the New Tork Federal Reserve Bank as the Deak
The decisions on the exact liming and amount of drily buving and selling operatons of securities in Julfiling the Committees dired we are he responsibility of the Acoount Manager at the Trading Desk of the New York Bank Wach Nowning, he and his staff lecde on a program 101 open narket operations to be undertaken that day, in developing this prognam, noney and credit anaket conditions and aggregate fargets desired by the Committee are considered as well as oller factors which nay be of concem at that ther Wach moming, the Account Manager places a conference eall to stall nembers of the board of Governors and one voling president to give infoma tion abunt present manlet conditions and open market operations which he joposes to execute that day: Other nembers of the Committee are inforned of the dail, progran by wire sumnary.

A summar of the Committees actions is pre sented to the jublic in the "Record of Policy Actions" of the Tederal Open Warket Commitee. This "Record" is released bout 90 days after ereh meeting and is publuhed in both the Ammat Report of the Board of Gouentro of the Tedent Rescroe Sustem eacl spring and in the Tedend Resere buheth each month The Theend? for earh meeting generally Malles.

1) a simnart of lecent economic develophents. such as prices, emplownent, industrial produce fion and components of the wational ineone accounts: also, staft projections concerning rea output growth for the current and following qualters are ustally discrissed

$2)$ a Uiscussion of lin U S balance of payments, incliding internationdt financial developments,

3) a discussion of interest rato novenents;

4) a discusston of open nanket operations and growh of reserve aggregates since the last neeting.

5) a discussion of the novenents of monetary ag gregates such as, Mr and $\mathrm{M}_{2}$, and the adjusted credit proxy'?

6 a generd statenent of the views of the members of the FONC:

$7)$ conclusions of the $\mathrm{FOMC}$.

8) a polics dreetive issued by the rOMC,

9) a list of the roting position of members and any dissenting comments.

2Mt tefers to the noney stock defned as brivate denand deposits phes curenes in the hands of the nonbank public

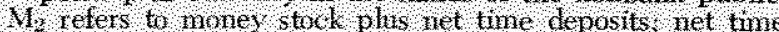
debosits are defhed a 10 al the deposits af all commerial barks wimus harge the centificates of deposit at $1 \mathrm{arge}$ weekly reporting commercill banks, Adiusted credit proxy is flefined as nenber banit deposits subect to reserve re quirenents olus bank-related commercial paper Eurodollar borrowings of $\mathrm{V} \mathrm{S}$ banks, and certain other nondeposit itents. 
(1)

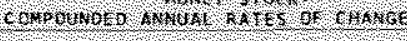

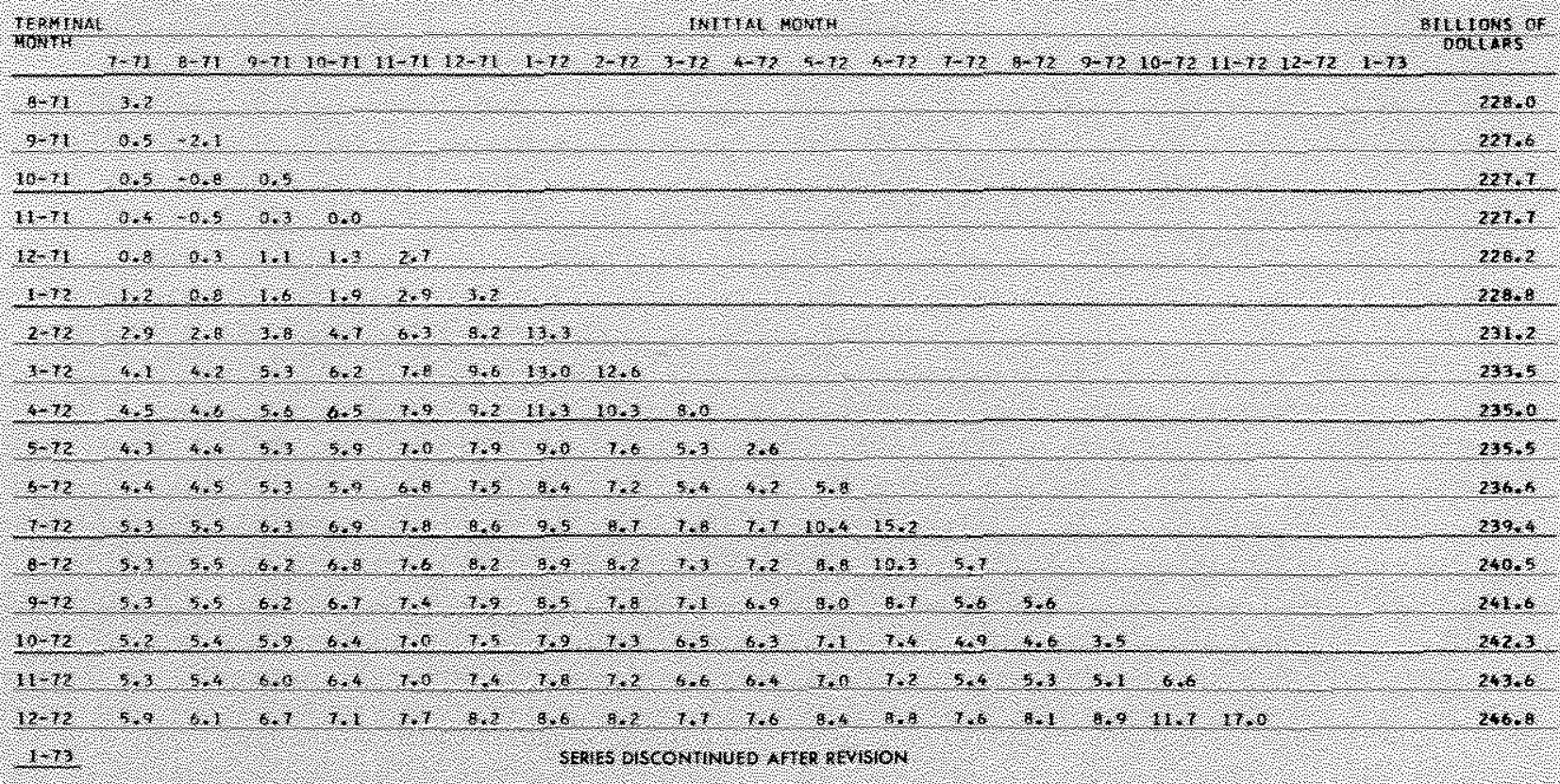

2.13

t)

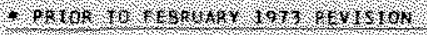

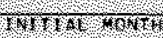

4townat

Howtil

4.7 .4 .6 .6

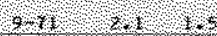

$10,1,0,0,0,8,8$

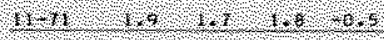

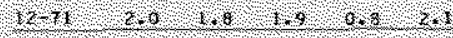

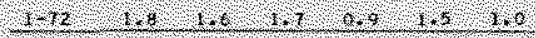

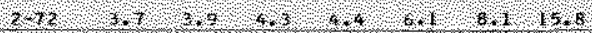

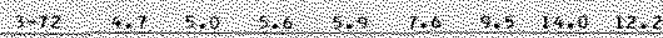

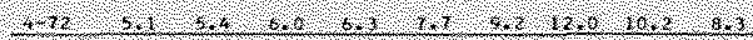

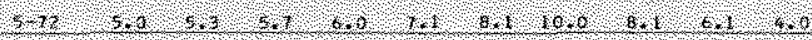

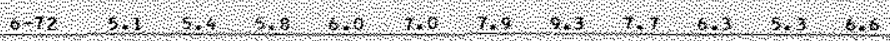

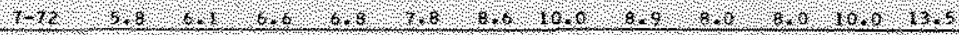

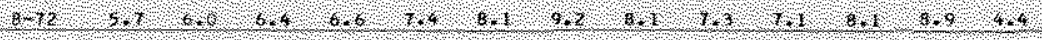

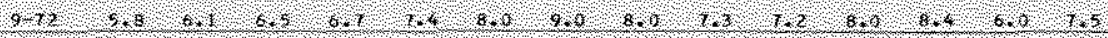

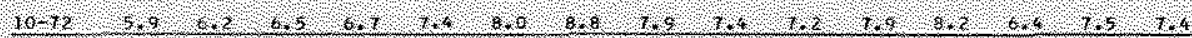

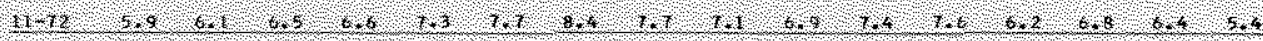

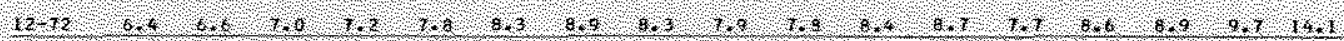

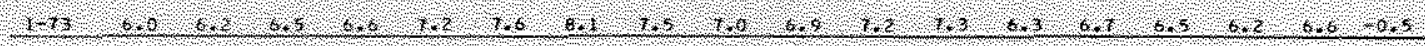

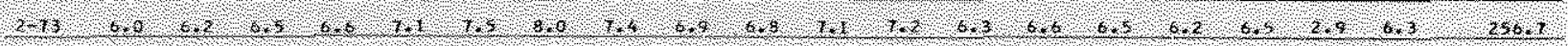

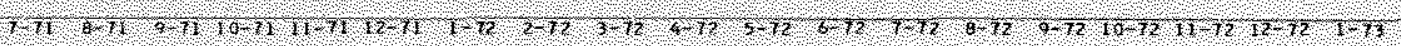

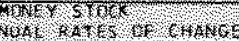

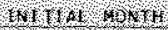

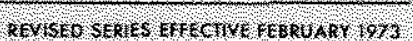

8,10040

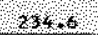
$234,5$.

235.

235.6 .

230.0

36.2

23.1.

44.19.9.

4.2.:.

$4,4.6$.

$2,5.1$.

29.7 .1

24.6.

253.1.

25.6.

252.7

25.5.

2.5 .4

\section{और}


This wording, which was repeated at the January 1972 meeting, indicates that at that time, with the existence of a price-wage control program, the Committee gave greater weight to providing the growth of money and credit which they viewed as essential to real economic recovery. A review of operating instructions issued in 1971 shows that for several months prior to the imposition of the price-wage freeze, the FOMC desired to slow the growth in monetary aggregates from the very high rates of the first half of the year. At the September and October 1971 meetings the Committee had agreed to seek "to achieve moderate growth in monetary and credit aggregates. ..." However, by November, after a few months of slower growth, the consensus had moved to one of desiring more rapid growth.

This qualitative phrasing of the growth rates of monetary aggregates sought by the policymakers is characteristic of the "Record of Policy Actions" of each meeting in 1972. Thus, the reader has only a general impression of the rates of growth that would be satisfactory to the Committee. At previous meetings, mostly from February 1970 to May 1971, the directive indicated specific growth rates of the money supply or other monetary aggregates that were being sought. This practice was not followed in the secondhalf of 1971. Then, at the January 1972 meeting, the "Record" began to report an objective of the Committee in terms of a specific range for the rate of growth of a measure of bank reserves. Specified at each subsequent meeting was a "target" growth rate of reserves which was deemed consistent with the Committee's desired growth rates for monetary aggregates. However, the rates of monetary aggregates were not specified, and because of the possibility of anticipated changes in the reserve-money multiplier, one cannot assume that a change in the target growth rate of the reserve aggregate would be accompanied by a similar change in the desired growth of the money supply and other monetary aggregates.

The policy consensus and the operating instructions included in the economic policy directive issued at the January 1972 meeting contained essentially the same wording as a month earlier. However, by this time there were apparently significant differences in the views of some members of the Committee. The policy directive had been adopted unanimously at the December 1971 meeting, but in January three votes were cast against the directive.

- $F_{O F}$ a more detailed discussion of reserve operating targets, see Charlotte E. Ranebling, "RPDs and Other Reserve Operating Targets," this Review (August 1972), pp. 2-7.
The reasons given for the dissents reveal some of the differences concerning the implementation of policy. The text of the "Record of Policy Actions" for the January meeting summarizes the majority view:

In the Committee's discussion considerable concern was expressed about the persistent sluggishness of key monetary aggregates, and a number of members advocated action to provide sufficient reserves to support the faster monetary growth that they believed was required by the economic situation and outlook. It was noted in this connection that the level of nember bank reserves, as well as that of $\mathrm{M}_{1}$, had changed little during the fourth quarter despite a progressive easing of money market conditions. In the interest of assuring the provision of reserves needed for adequate growth in monetary aggregates, the Committee decided that in the period until its next meeting open market operations, while continuing to take appropriate account of conditions in the money market, should be guided more by the course of total reserves than had been customary in the past....

In placing greater emphasis on total reserves, the Commitiee took note of a staff analysis suggesting that moderate rates of growth in $M_{1}$ and $M_{2}$ in January and February were likely to be associated with a large increase in total reserves from December to January and then a decline in February - mainly as a consequence of recent and anticipated changes in U.S. Government deposits, and allowing for the 2-week lag between member bank deposits and required reserves. Against the background of this analysis, a majority agreed that an annual rate of growth in total reserves of roughly 20 to 25 per cent from December to January would be satisfactory, provided that it conld be attained without undue easing of money market conditions.

\section{Following the directive, the "Record" notes:}

Messis. Hayes, Brimmer, and Kimbrel differed somewhat in their reasons for dissenting from this action. Mr. Hayes considered the emphasis placed on total reserves as an operating target to be an undesirable step; in his judgment, reserves were much less meaningful than other measures, such as the monetary and credit aggregates and interest rates, as an instrument for working toward the Committee's basic economic objectives. Also, he was reluctant to issue a directive that might involve a substantial further easing of money market conditions, since the Committee had already moved rapidly in that direction and since it appeared to him that the economic outlook had improved somewhat in recent months. He was concerned about the risk that a further sharp decline in short-term interest rates might subject financial markets to unnecessary whipsawing and might tend to rekindle inflationary expectations.

$\mathrm{Mr}$. Brimmer shared the majority's views concerning broad objectives of policy at this time, and he 


\section{EXHIBIT I}

Date of

FOMC

Meeting

1971

\section{Policy Consensus}

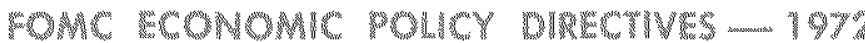

Operating Instructions

In light of the foregoing developments, it is the policy of the Federal Open Market Committee to foster financial conditions consistent with the oims of the new governmental program, inciuding sustainable real economic growth and increased employment, abalement ot intalionary pressures, and ankinmem of reasonable equithesum in the county's balance of payments.

January 11 , No Change

1972

February 15

to foster financicl conditions conducive to employment abatement of infationary pressures, and attoinment of reasonable equilibrium in the country's balance of payments.

March $21 \quad$ No Change

FOMC REORGANIZED WITH NEW VOTING MEMBERS

while taking account of international developments and possible Treasury finoncing, the Committee seeks to achieve bank reserve and money market conditions that will support moderate growth in monetary aggregates over the months ahead.

Dissents: Nane

April is No Change

.. while taking account of capital market developments and the forthcoming Treasury financing the Comments and the fonthe commitse tions the will support somewhet more moderele grow in monetary aggregales over

\section{Dissents: None}

Moy 23 No Change

while taking account of capital market developments and possible Treasury refunding, the Commillee seeks to achieve bank reserve and money market conditions that will support somewhat slower growth in monetary aggre. gates over the months ohead

Dissents: None

Absent and not voting: Mr. Robertson

June 19-20 No Change

while laking account af possible Treasury financing and developments in copilal markets, the Committee seeks to achieve bank reserye and money market conditions that witl support moderate growth in monetary aggragates aver the months ahead? ${ }^{3}$

\section{Operating Target}

Dissents; None

Absent and not roting: Mr. Hayes

(Mr. Treiber voled as his alternate) 
July 18 No Change

August 15 No Change

September 19 No Change

October 17 No Change

November No Change

20-21

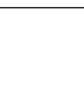

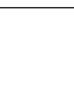

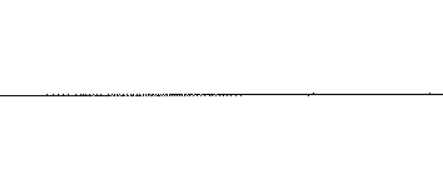

\section{financing, while taking account of the fortheoming Treasury financing, developments in copital markets, and interna-} tional developments, the Committee seeks to ochieve bank reserve and money market conditions that will support moderate growth in monetary aggregotes ower the fronths ahead.

Dissents: Mr. Coldwell

Absent and not roting: Mr. Mitchell

.. While taking account of developments in capilat matkets and internotional developments, the Committee seeks to achieve bank reserve and money market conditions that will support moderate growth in monetary aggregates over the moniths ohead.

Dissents: None

.. while taking special account of the effects of possible bank regulatory changes, developments in credit markets, and international developments, the Committee seeks fo achieve bank reserve and money market conditions that will supporf more moderate growh in monetary oggregates over the months ahead.

Dissents: Mr. Maclaury, Mr. Robertson

Absent and not voting: Mr. Winn

(Mr. Mayo voted as his alternate.)

.. While taking account of the effects of possible bank regulatory changes, Treasury financing operations, and developments in credit markets, the Commitfee seeks to achieve bank reserve and money market conditions that will support more moderate grawth in monetory aggregates over the months ahead than recorded in the third guates over.

Dissents: None

.. while laking account of the effects of recent bank regulatory changes, the Committee seeks to achieve bank reserve and money market conditions that will support more moderate growth in monefary aggregates over the months ahead than recorded in the third quarter.

\section{Dissents: None}

Absent and not woting: Mr. Coldwell

(Mr. Francis voted as his alternate.)

December 19 No Change

. while taking account of Treasury financing operations and possible credit market developments, the Commitfee seeks to achieve bank reserve and fions that will supporf slower growth in monetary aggregates over the months ohead

Dissents: None $\therefore$ it [the Committee] decided to seek growth in RPD's at an annual rate in a range of 3107 per cen during the July-August period while continuing to avoid sharp fluctuations and large cumulative changes in money market conditions.

It [ the Committee] decided to seek growth in RPD's during the August-September period at on annual rafe in a range of 5 to 9 per cent. . .

The Committee took note of a staff analysis suggesting that an average rate of expansion in RPD's in Seplember and Octaber in a range equivalent to $9.5 \mathrm{lo}$ 13.5 per cent would be likely to lead to more moder afe growth in monelary aggregates over the months ahead. 4

.. the Committe decided that its objectives for the aggregates would be fostered by growth in RPD's during the October-November period at an annugl rote within a range of 6 to 11 per cent. 6

the Committee decided that its objectives regarding the aggregates would be served by open marke operations directed of fostering growth in RPD's during the November-December period at an annual rate with. in a range of to to 10 per cent, while continuing to ayoid marked changes in money morket conditions.

They detided that open market operations should be directed at fostering RPD growth during the 2-month period within a range of 4 to 11 per cent while continuing to avoid marked changes in money marke conditions.

IOn December 20, 1971, the phrase "while taking account of international developmentas" was added.

${ }^{2}$ At the February 1972 meeting the Committee decided to express its reserve objectives in terms of reserves availubse to support private nonbank deposits (RPDs), defined specifically as total member

50 July 6, 1972, the phrase "and international developments," was atded.

The figures cited were based on the assumption that Regulations $D$ and $J$ would not become effective during this period.

$F$ The range of tolerance for the RPD growth rate was modified to 9 to 14 percent dute to the amendronts to Regulations $\mathrm{D}$ and $\mathrm{J}$

NOTE: Emphasis added by this Bank. 
indicated that he would have voted favorably on the directive were it not for the decision to give special emphasis to total reserves as an operating target during coming weeks. In his judgment the Committee should have had more discussion of the implications of that decision, and in any case it should have postponed the decision until after it had held a contemplated meeting to be devoted primarily to discussion of its general procedures with respect to operating targets.

Mr. Kimbrel favored supplying reserves at a rate that would accommodate orderly economic expansion. He voted against the directive because he thought it involved risks of depressing short-term interest rates to unsustainably low levels and of producing excessive rates of growth in the monetary aggregates in the future.

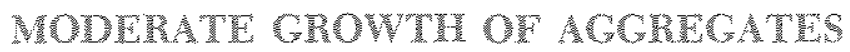 - FERUA}

When the Committee met again in February it established a policy consensus which was similar to those adopted during the previous six months. The essential difference was deletion of reference to "the aims of the new governmental program. ..." Throughout the remainder of the year there was no change in the policy consensus.

The operating instruction included in the directive issued at the February meeting was less expansive in tone than the previous two. As intended, a large growth in bank reserves had occurred between the January and February meetings, and the desired acceleration in the growth of monetary aggregates had begun. Consequently, the Committee decided to seek conditions that would "support moderate growth in monetary aggregates. ..."

To achieve its near-term objectives, the Committee modified further the operating target. The use of total bank reserves had been adopted only a month earlier, but at the February meeting

... the Committee decided to express its reserve objectives in terms of reserves available to support private nonbank deposits [RPDs] - defined specifically as total member bank reserves less those required to support Government and interbank deposits. This measure was considered preferable to total reserves because short-run fluctuations in Government and interbank deposits are sometimes large and difficult to predict and usually are not of major significance for policy. It was deemed appropriate for System open market operations normally to accommodate such changes in Government and interbank deposits.

The Committee agreed that the economic situation and outlook at this time called for growth in the

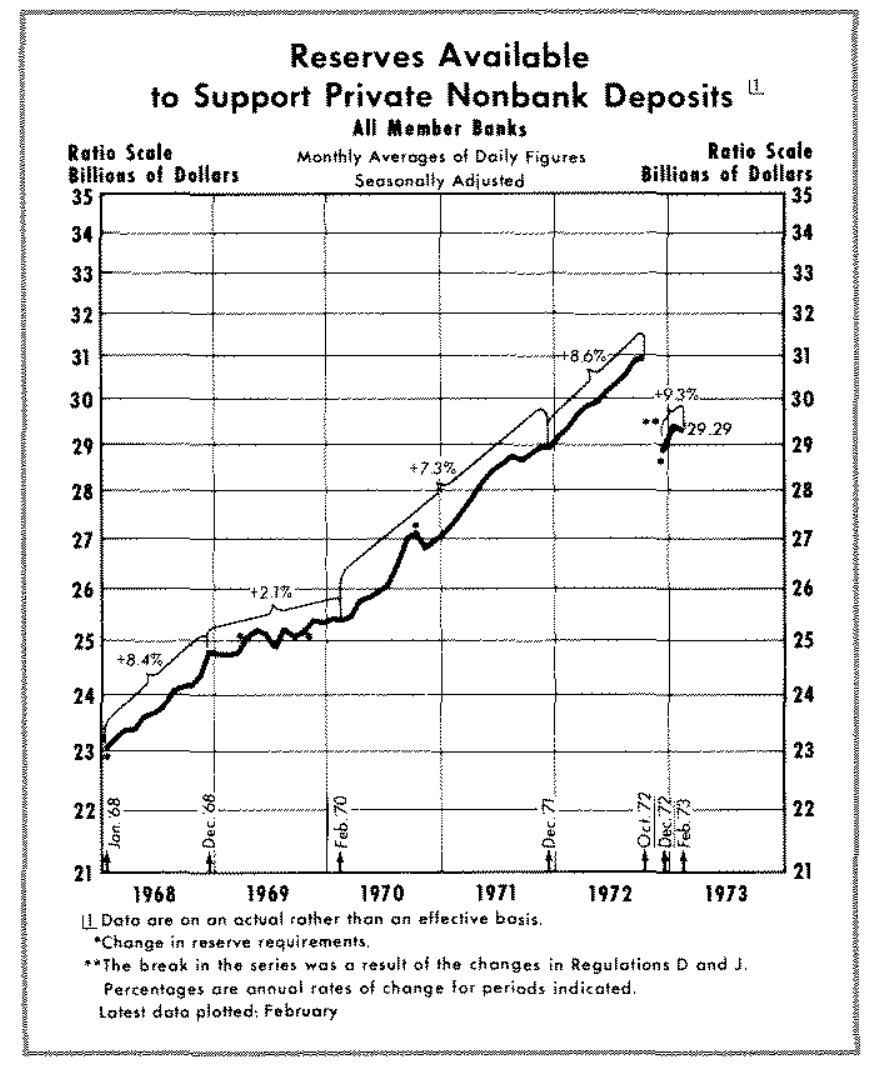

monetary aggregates at moderate rates. It took note of a staff analysis suggesting that, over the months of February and March combined, such growth was likely to be associated with expansion in the reserve measure employed at about an 8 per cent annual rate, and possibly with some firming of money mar. ket conditions. The members decided that it would be desirable to seek growth in the reserve measure in the Febnuary-March period at an annual rate in a range of 6 to 10 per cent, while avoiding both sharp short-run fuctuations and undesirably large cumulative changes in money market conditions in either direction in the period between meetings. They also decided that some allowance should be made in the conduct of operations for any significant deviations that might develop between the actual rates of growth in the monetary aggregates and the moderate growth rates expected.

\section{Mr. Hayes dissented from this action}

... for essentially the same reasons he had dissented from the directive adopted at the previous meeting. First, he did not favor placing as much emphasis as contemplated on reserves as an operating target; he preferred to place main emphasis on money market conditions for that purpose. Second, he thought the policy agreed upon could result in an easing of money market conditions to a degree that in his judgment would entail substantial risks both domestically and internationally.

Another new element at the February meeting was introduced: 


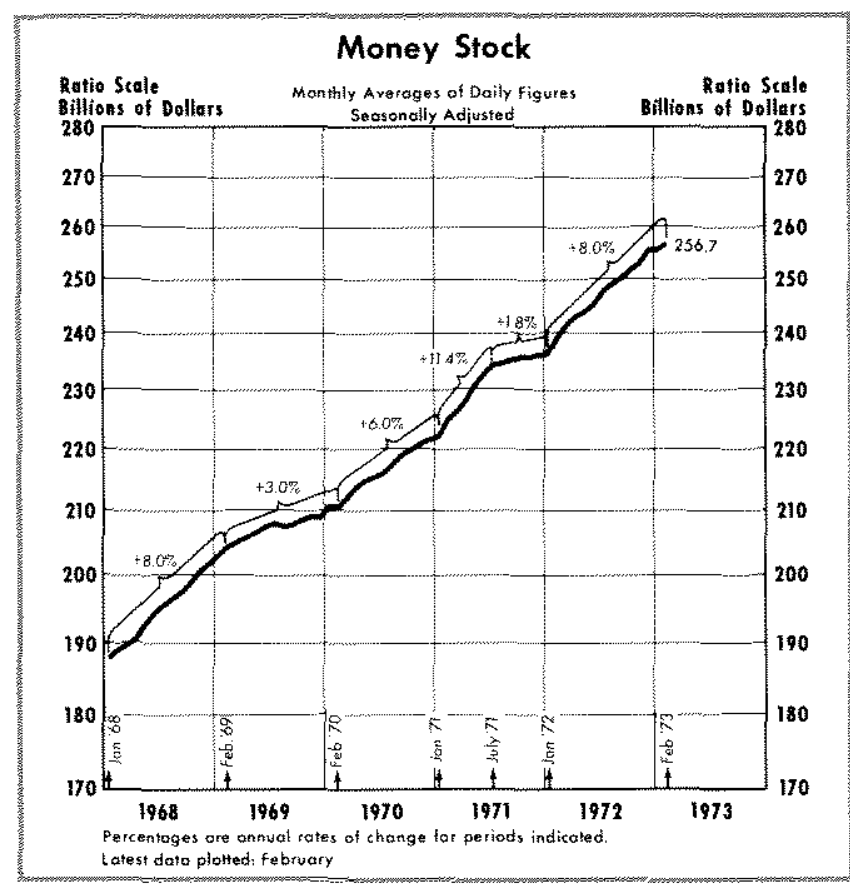

. . . it was understood that the Chairman might call upon the Committee to consider the need for supplementary instructions if it appeared during the period before the next scheduled meeting that the Committee's several objectives and constraints were not being met satisfactorily.

The understanding was repeated in the "Record of Policy Actions" for each of the subsequent meetings through the remainder of 1972 .

Some perspective on a prominent view of the role of monetary policy early last year might be gained from reference to Chairman Bums' testimony on February 9,1972 before the Joint Economic Committee. Regarding monetary developments, the Chairman noted

.. the role that monetary policy needs to play in furthering national objectives this year. Clearly, our monetary affairs - no less than our fiscal affairs must be kept in order, so that public confidence in our monetary management is maintained. An unduly expansive monetary policy would be most unfortunate, particularly in view of the large Federal budgetary deficits now projected. We need always to be mindful of the fact that increases in money and credit achieved today will still be with us tomorrow, when economic conditions may no longer be the same as they are today.

At this stage of the business cycle it is essential to pursue a monetary policy that will facilitate good economic recovery. Supplies of money and credit must be sufficient to finance the growth in consumer spending and in investment plans that now appears in process. Let me assure this committee that the Federal Reserve does not intend to let the present

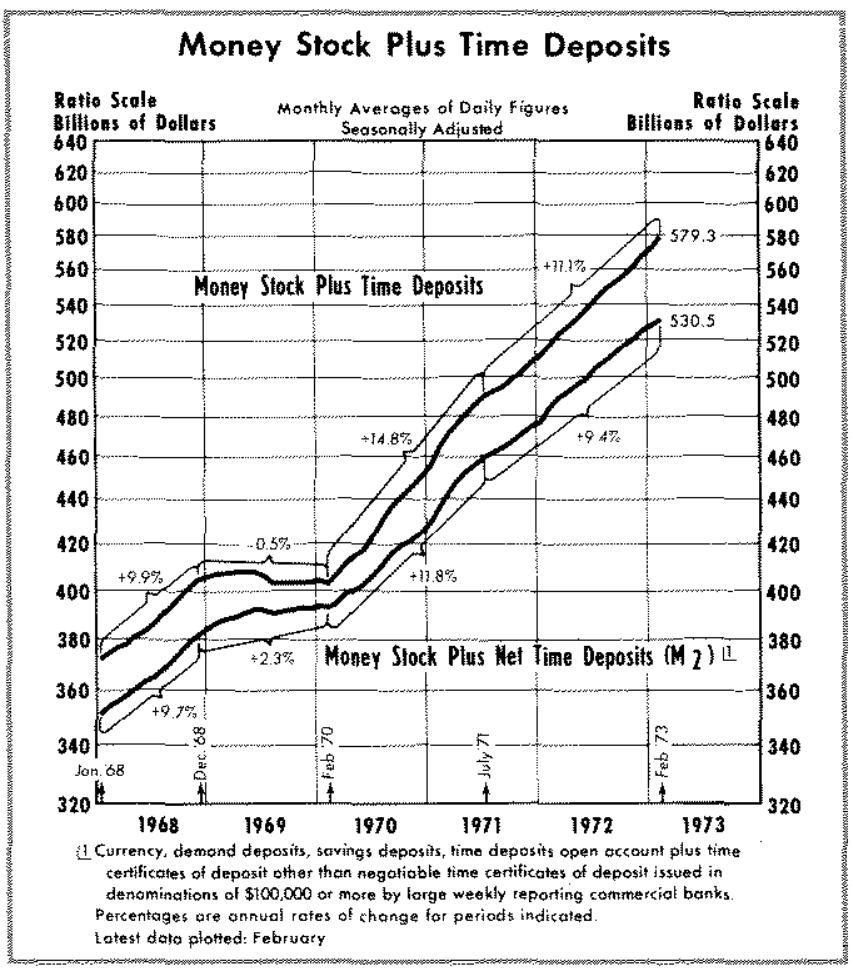

recovery falter for want of money or credit. And let me add, just as firmly, that the Federal Reserve will not release the forces of a renewed inflationary spirat.

We are now in a favorable position to provide the monetary support needed for a quickening pace of production and employment. While expansion in the supply of money and credit was relatively brisk during 1971 , we successfully avoided an unduly rapid growth of liquidity.

No single measure of money of credit represents adequately the impact of monetary policy on the economy. Let the nevertheless cite a few salient facts. Growth of the narrowly defined money supply - that is, currency and private demand deposits - amounted to 6.2 per cent during 1971 , compared with 5.4 per cent in 1970 . If the money supply is defined more broadly, so as to include also consumertype time and savings deposits at commercial banks, the rate of growth was 11.1 per cent during 1971 , compared with 8.1 per cent in the previous year.

These 1971 growth rates of money balances are at the upper end of the range witnessed over the postwar period. That is what should happen at a time of stuggish economic growth, as this committee has pointed out. [Federal Reserve Bulletin (February 1972), pp. 125-126.]

After reviewing the monetary policy actions of the previous year, Mr. Burns also remarked:

In recent months, the Federal Reserve has sought to encourage a faster rate of monetary expansion than occured in the late summer and fall of last year. Open market operations have been conducted 
with more emphasis on increasing the reserve base of the barking system. In the 5 months from September through January, total bank reserves rose at an annual rate of over 8 per cent. Thus far, much of this increase has supported an accelerated growth in time deposits. But, in due course, the narrowly defined money stock, on which so much emphasis is nowadays placed by some single-minded observers, will also respond; preliminary calculations indicate that this aggregate rose more rapidly in January than in the immediately preceding months. [Ibid, p. 127.]

For the meeting on March 21 the "Record" notes the fact that yields on short-term market sectrities had risen considerably in recent weeks. This was a largely expected development following the very sharp declines in short-term rates that had occurred in late 1971 and the first few weeks of 1972 . It was pointed out in the "Record" that the spread between rates on short- and long-term securities had been extremely wide by historical standards, and it remained wide even after the recent rise in short-term rates. The staff analysis indicated that a moderate growth in monetary aggregates during March and April combined would likely be associated with an 11 percent rate of growth in RPDs and some further tightening in money market conditions.

As cited above, the Committee directives for December 1971 and January 1972 had called for greater growth in the monetary aggregates over the months ahead. In order to achieve this greater growth, a majority of the Committee at the Jantuary meeting had voted to increase total bank reserves at a $20-25$ per. cent annual rate from December to January. This effort was clearly successful by the March meeting where

... it appeared that over the first quarter $\mathbf{M}_{\mathrm{F}}$ and $M_{2}$ would expand at annual rates of about 9.5 and 13.0 per cent, respectively, and that the bank credit proxy would rise at a rate of about 10.5 per cent.

However, regarding this increase, it was noted that $M_{1}$ "increased sharply in February - in part because of a substantial reduction in $\mathrm{U}, \mathrm{S}$. Govemment deposits at commercial banks."

The growth of the narrowly defined money stock accelerated to a 9.6 percent annual rate in the period from December 1971 to March 1972, compared with a 1.1 percent rate of increase in the previous three months. Staff projections at the March meeting sug-

Quarterly growth tates cited are calculated on the busis of the daily-average level in the last month of the quarter relative to the last month of the preceding quarter.

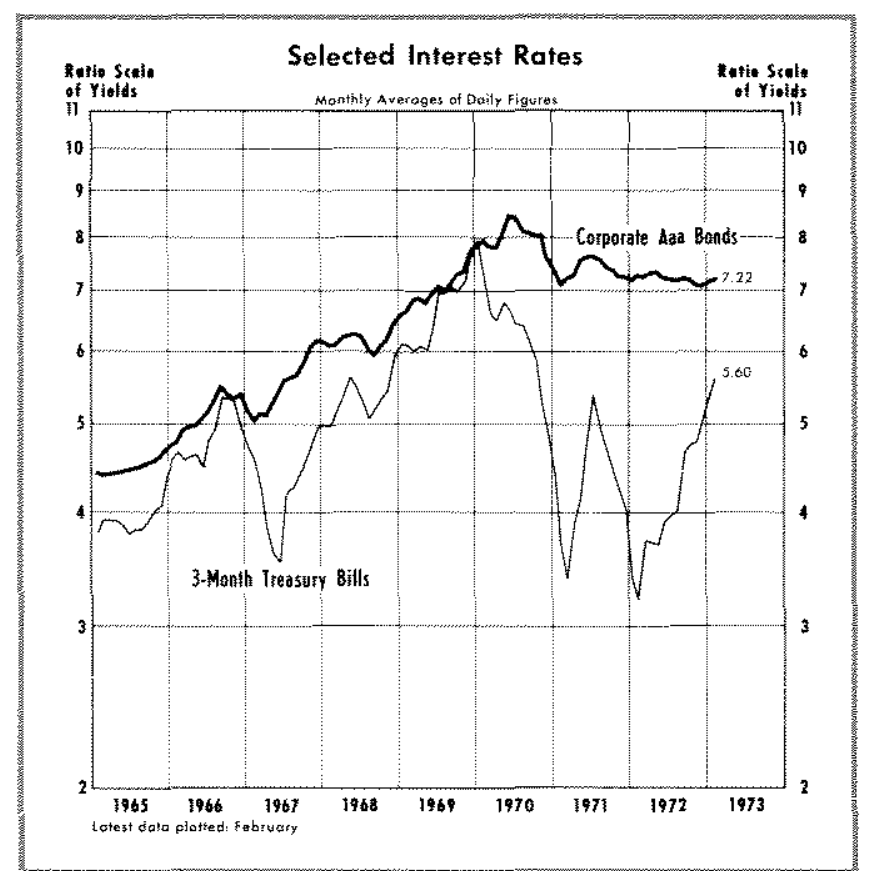

gested a somewhat faster growth in real GNP in the second quarter than in the first, and the Committee agreed that the

... economic situation continued to call for moderate growth in the monetary aggregates, although at rates less rapid than those likely to be recorded for the first quarter.

\section{BHe - A}

According to the "Record" for the Committee meeting in mid-April, the economic outlook at that time appeared almost the same as a month earlier. In view of the projections of a continually strengthening economy in 1972 , the monetary authorities indicated a desire to avoid providing excessive stimulus. At the April meeting

The Committee agreed that the economic situation called for growth in the monetary aggregates at rates somewhat more moderate than those recorded for the first quarter of the year.

When the Committee met again five weeks later they "agreed that the economic situation called for growth in the monetary aggregates over the months ahead at rates somewhat slower than those recorded in recent months." However, to achieve this objective, after taking account of lagged reserve requirements and recent changes in deposits, the Committee spectfied a range of growth in RPD that was slightly higher than the range indicated at the previous meeting, and 


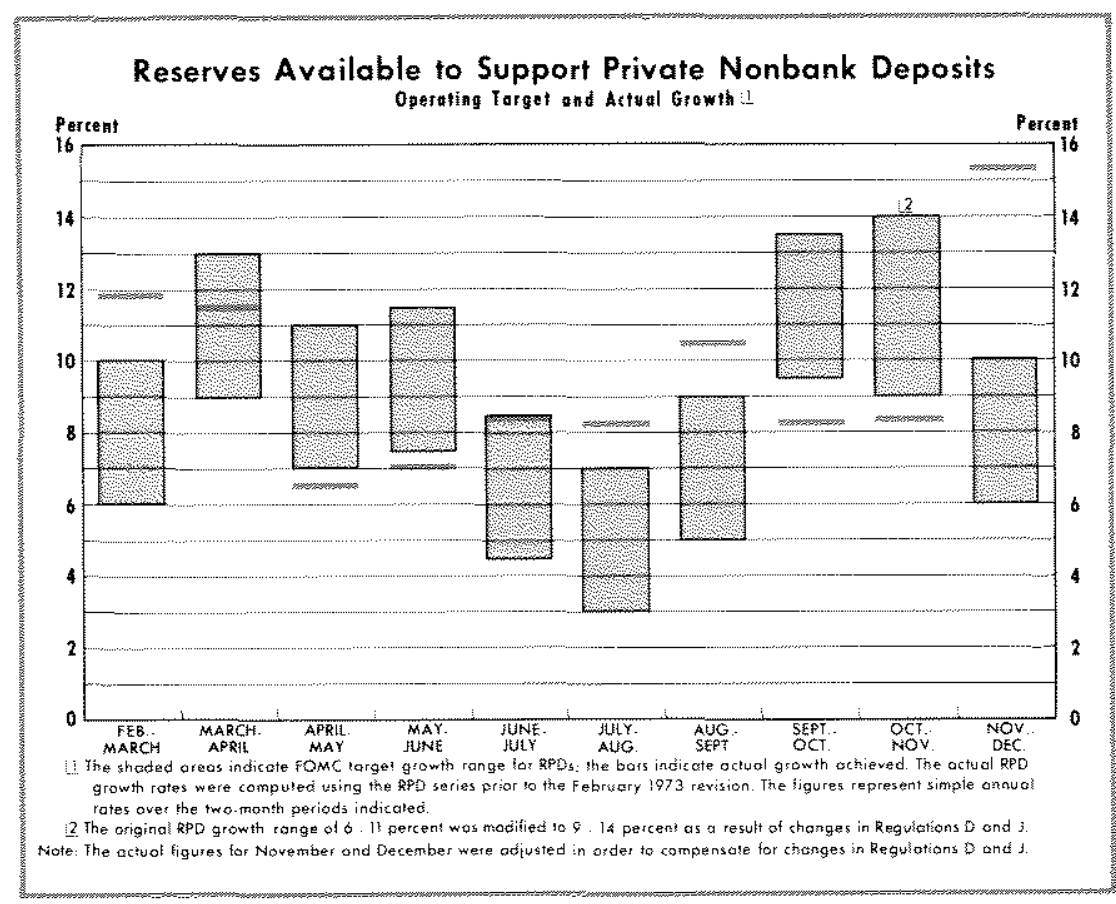

what more moderate growth" and "somewhat slower growth" in monetary aggregates over the months ahead, respectively. At the June meeting the desired range of RPD growth had been significantly reduced. Apparently, though, the results were different than expected. The "Record" for the July meeting, after noting that the growth of $\mathrm{M}_{1}$ in June was at the same relatively slow rate of May, stated:

Sluggishness in June, however, may have reflected temporary effects of the speculation in foreign exchange markets and outflows of funds from the United States after mid-month, and weekly data suggested a sharp increase in the rate of expansion in early July.

The idea underlying the reference to "outflows of funds from the United States" is complex. During such an

the lower end of which was the same as recent experience. Thus, at the April meeting they had specified a range of RPD growth of 7 to 11 percent, and at the time of the May meeting it appeared their actions had resulted in growth of these reserves at at 7.5 percent rate. The consensus was to seek a somewhat slower rate of growth in monetary aggregates; the range of RPD growth for the May-Iune period was specified to be 7.5 to 11.5 percent.

\section{ACTEVNG MODERATE GROWTI- JUNE TO AUGUST}

A month later it appeared that growth of RPDs in the May-June period would be at the lower end of the specified range, and growth of the narrowly defined money stock had slowed further. The Committee lowered its desired target range of BPD growth to 4.5 to 8.5 percent during the June-July period. As usual, "the members also decided that some allowance should be made in the conduct of operations if growth in the monetary aggregates appeared to be deviating significantly from the rates expected. . .."

The provision for a change in the conduct of operations under certain conditions would appear to have become of some importance in view of the events around mid-year. The decisions and actions of the preceding few months had been in the direction of less rapid growth of monetary aggregates than had occurred early in the year. The operating instructions of the April and May meetings had called for "some- "outflow" there is a change in ownership of demand deposit accounts at U. S. commercial banks, wherein deposits of domestic holders are reduced (initially and temporarily) and holdings of foreigners (individuals, governments, banks, or other firms) are increased. Since the U. S. money stock is defined to include deposits of foreigners, a change of ownership of demand deposits from U.S. residents to foreigners does not influence the quantity of money outstanding unless government deposits are also changed.

The reference to "a sharp increase in the rate of expansion in early July" is another matter. Mid-year "window-dressing" by commercial banks, and the occurrence of the July 4 holiday on Tuesday of the same settlement week, may have contributed to an unusually large increase in net demand deposits at member banks in the first week of July. ${ }^{7}$ Similar temporary lluctuations have occurred on other occasions, and over the subsequent few weeks the growth of the money supply returned to its previous trend. However, instead of an offsetting drop in demand deposits following the mid-year bulge, the level of deposits plateaued at the high level. The growth rate of money for the month of July was at a 15 percent annual rate, and in August the growth rate of money was reduced to only a 5.7 percent rate. ${ }^{8}$

\footnotetext{
"For nonbusiness days, banks use the balance of the preceding business day. During the week ending Jtuly 5 , banks carried the large Jine 30 balances for three days, resulting in a large increase in the weekly average net demand deposits.

"The "revised" money stock series shows an increase in money from June to July at a 13.5 percent rate, and an increase at a 4.4 percent rate from July to August.
} 
This episode may illustrate some of the problems associated with short-run monetary management, especially under a system of lagged reserve requirements. The deposits of banks in any given week are relatively independent of the amount of reserves in the banking system that week, but the Federal Reserve is obliged to provide reserves - either through open market operations or through the discount window - to meet the requirements based on the deposits of two weeks earlier.

The operating instructions issued at the July 18 meeting were the same as had been issued at the June meeting, namely "the Committee seeks to achieve bank reserve and money market conditions that will support moderate growth in monetary aggregates over the months ahead." Mr. Coldwell dissented from this action

. . . because in his judgment average growth in bank reserves within the specified range for July and August and the associated expansion in the money supply might build a base for excessive economic stimulation. He was concerned about the effects both on the domestic economic situation, in the context of heavy stimulation from fiseal policy, and on international financial problems.

The "Record" for the August 15 meeting noted the very rapid growth of the money stock in July, but no reason for the sharp rise was reported. The report to the Joint Economic Committee of Congress regarding the "Financial Developments in the Third Quarter of 1972 " states, "Over the third quarter, $\mathrm{M}_{1}$ grew at an 8.5 percent annual rate, but this mainly reflected increased public demand for cash balances early in July." [emphasis added]

In view of the then current rapid growth of aggregates, the "Record" reports that following the July meeting "the System undertook to slow the increase in reserves to the extent feasible in light of the largescale Treasury refunding then in process." While continuing to desire to hold down monetary growth in the coming period, an increased concern about interest rate movements was expressed:

The Committee agreed that the economic situation continued to call for moderate growth in the monetary aggregates over the months ahead. If decided to seek growth in RPD's during the August-September period at an annual rate in a range of 5 to 9 per cent - a rate which was expected to be associated with some moderation in monetary growth. While recognizing that pursuit of the objective for RPD's

9Federal Reserve Bulletin (November 1972), p. 947.

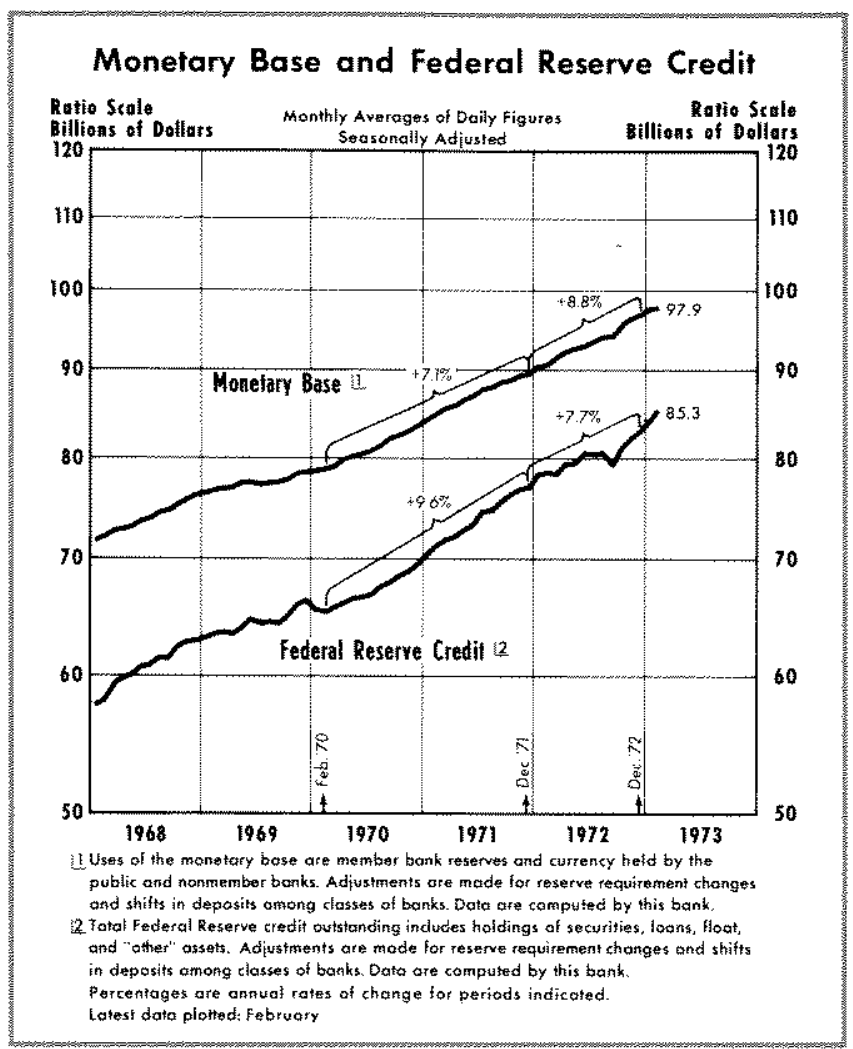

might be associated with some firming of money market conditions, the Committee agreed that $a$ marked frming, which might precipitate unduly sharp increases in interest rates in a sensitive market atmosphere, should be avoided. [emphasis added]

In commenting on the rapid growth of RPDs in the third quarter, the report to the Joint Economic Committee emphasizes the different avenues through which the Federal Reserve provides reserves to the banking system. The report notes that "reserves provided through open market operations were held back and more than half of the increased demand for reserves was obtained by banks through enlarged borrowing from Reserve Bank discount windows."10 During that period short-term market interest rates tended to rise, with relatively sharp increases occurring in the second half of the quarter. Prior to August the Federal funds rate (the rate at which banks borrow reserves from each other) had been mostly below the Federal Reserve Banks' discount rate. Since that time the funds rate has generally been rising relative to the discount rate, making borrowing from Federal Reserve banks a relatively cheaper source of short. term funds to banks. The accompanying chart shows the movement of short-term interest rates in this period.

10 Ibid. 


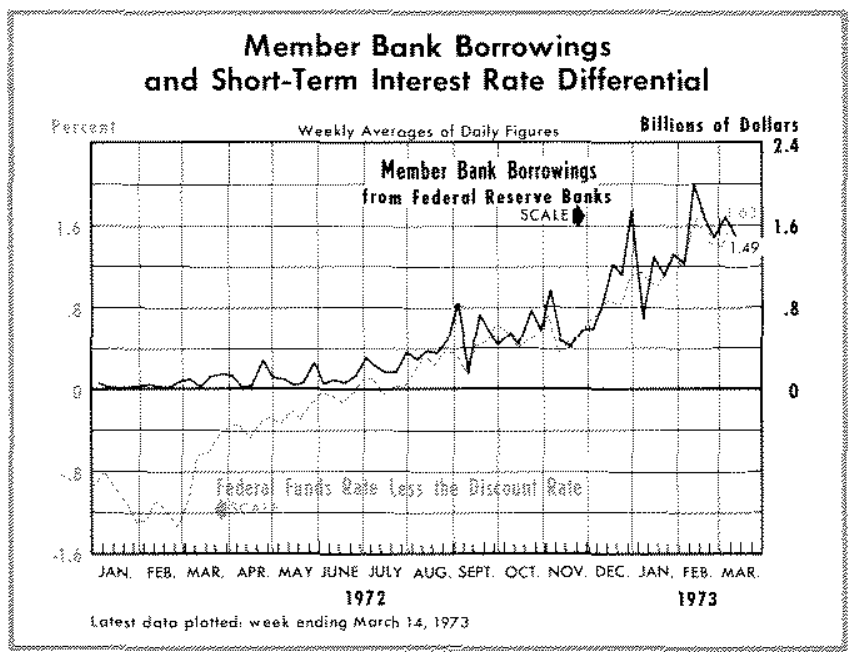

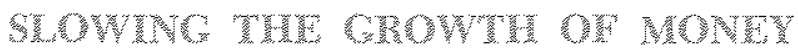

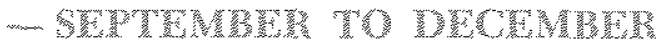

At the final meeting of the quarter, the economic outlook was for an even stronger growth of GNP in the fourth quarter than in the third. GNP growth was seen to remain at a fast pace in the first half of 1973. Analysis prepared for the September meeting included discussion of the factors contributing to sharp increases in short-term market interest rates in the period between meetings. The Committee's target from the previous meeting was for growth of RPDs between 5 and 9 percent ssubject to the proviso that money market conditions should not be permitted to firm markedly."

Pursuit of the RPD target was complicated by the need to absorb reserves at a time when the market supply of Treasury bills was increasing. Early in the period, RPD's - and the monetary aggregates - appeared to be expanding rapidly. As the System acted to restrain growth in reserves, short-term interest rates began to rise sharply and financial markets became increasingly sensitive; this was especially evident just before the Labor Day weekend when a number of banks misjudged their reserve needs and bid the Federnl funds rate up as high as $51 / 2$ per cent. In order to avoid a marked firming in money market conditions and unduly sharp increases in interest rates, for a time the System supplied reserves more generously.

For the coming months the Committee desired to slow the growth in monetary aggregates from the rates of the third quarter; however, "the members noted that conditions in financial markets were still highly sensitive." Because of this condition and the possibility of regulatory changes, the members decided that in seeking an annual rate of RPD growth in a 9.5 to 13.5 percent range

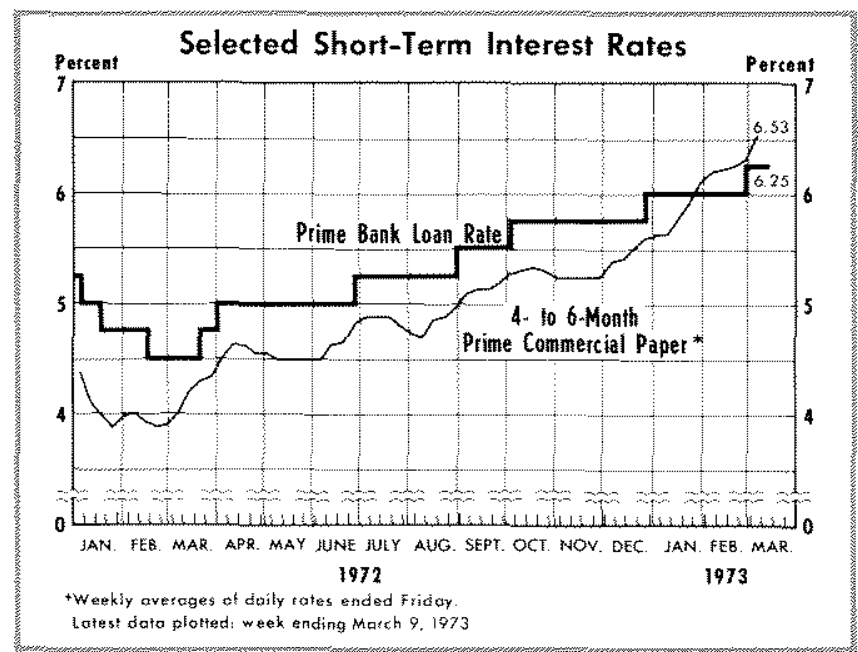

... the System Account Manager should have more than the usual degree of discretion in making operating decisions and that he should give more than customary attention to money market conditions, while continuing to avoid marked changes in such conditions.

There were two dissents from this directive, both based on concern about the rapid monetary growth.

Mr. Maclaury dissented from this action because he had become increasingly disturbed by the rapid rates of growth in the aggregates, given the prospective strength of the economy, and he felt that the Committee's current operating procedures did not assure that money market conditions would be permitted to tighten sufficiently to slow this excessive monetary growth in the near future.

Mr. Robertson dissented because of his belief that with the existing potentiality for increased inflationary pressures, the Committee was not doing enough to curb the rate at which reserves were being fed into the banking system by the Federal Reserve and to slow down the rate of growth in the monetary aggregates. In his view, the failure to do so might result in a new ground swell of inflation later on.

At the final three meetings of 1972 , the Committee made explicit in its operating instructions that lower growth rates of monetary aggregates were being souglit. The operating target adopted at the meeting of September 19 was for growth of RPDs in the range of 9.5 to 13.5 percent for the September-October period, "unless disturbances arose in financial markets or unless growth rates in the monetary aggregates appeared to be falling far short of expectations." At the October meeting RPD growth appeared to be at the lower end of the range, and it was noted:

The Federal funds rate was about 5 per cent in the days before this meeting, unchanged from the level prevailing just before the preceding meeting. 
In accordance with their desire for less rapid growth in monetary aggregates than in the third quarter, the Committee specified an RPD range of 6 to 11 percent for the October-November period "while continuing to avoid marked changes in money market conditions." 11

The directive issued at the November meeting was essentially the same as a month earlier, with the major difference being that the changes in Regulations $D$ and $J$ that had been pending for several months had been implemented on November 9 . The RPD range specified for the following twommonth period was 6 to 10 percent, and the proviso "to avoid marked changes in money market conditions" was repeated.

At the time of this meeting it appeared that RPD growth would be at only a 5.5 percent rate in the October-November period, compared with the revised target range of 9 to 14 percent specified at the October meeting. Regarding this slower growth, the "Record" states:

To a considerable extent, the short-fall in RPD's occurred because the relationship between reserves and monetary aggregates that evolved after the implementation of the amendment to the Board's Regulation $D$ differed from the relationship that had been expected.

At the final meeting of the year the outlook was for a continued strong economic expansion through the first half of 1973. The members of the Committee indicated a continued desire to curb further monetary growth as they issued a directive to achieve "slower rates than those that appeared likely to be recorded for the second half of 1972." [emphasis added] The "Record" for this meeting stated that since the prior meeting, operations had been conducted so as to "sup-

\footnotetext{
1.It was noted at this meeting that the amendments to Regulations $D$ and I, initially scheduled to become effective on September 21, 1972 but postponed as a result of court proceedings, might be implemented during the October-November period. Following the Board's decision on October 24 to implement the anendments as of November 9,1972 , the mange of tolerance for the $\mathrm{RPD}$ growth rate was modifed to 9 to 14 percen 1 a technical adjustrment to take account of the elfects of those regulatory actons on the relationship between reserves and the monetary aggregates.
}

port more moderate monetary growth than the annual rates of about 8.5 per cent for $\mathrm{M}_{1}$ and 9.5 per cent for $\mathrm{M}_{2}$ recorded over the third quarter."

The target range for RPDs had been 6 to 10 percent, but during much of the intermeeting period

. . the rate of growth in RPD's had appeared to be substantially above the specified range, and the System had acted to restrain expansion in nonborrowed reserves.

The directive for the December-January period specified a wider range for RPD growth than had been indicated previously. The Committee sought RPD growth in the range of 4 to 11 percent, and the reason given for this wider band was to allow the Committee to take account of
. . a staff analysis of prospective reserve-deposit relationships which suggested that the Committee's objectives for the aggregates might be served by fostering growth in RPD's during the December- January period at an anmual rate within a range of 7 to 11 per cent. However, in view of the rapid expansion in monetary aggregates since the preced- ing meeting, the members concluded that reserve- supplying operations that would result in an easing of money market conditions should be avoided un- less the anuual rate of RPD growh appeared to be dropping below 4 per cent.

And it was decided that in so doing they would continue "to avoid marked changes in money market conditions."

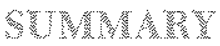

At year's end the policy consensus was essentially the same as a year earlier, but the direction of emphasis in monetary actions was reversed. The desire to achieve greater growth in monetary aggregates at the December 1971 and January 1972 meetings of the Committee would indicate that relatively greater weight was being given to promoting real economic growth. In contrast, late in 1972 the Committee instructed the Desk to achicve slower growth in the monetary aggregates in view of the economic situation and the rapid rates of growth in money that had occurred.

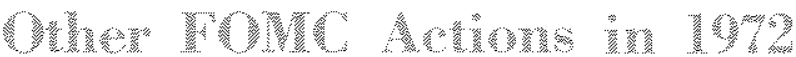

During 1972 the Federal Open Market Committee revised its rules with regard to the pricing of "repur" chase agreements" (RPs) arranged by the Federal
Reserve Bank of New York with nonbank dealers, and the limits on Federal Reserve holdings of the security issues of various Federal agencies. 


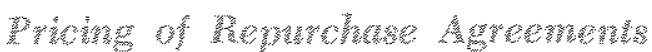

At a meeting on April 17, 1972 the FOMC amended its "continuing authority directive" with respect to open market operations. The change involved the method of determining the interest rates that would apply in arrangements between the Federal Reserve Bank of New York (the Desk) and nonbank security dealers, in which the Desk acquires short-tem securities from the dealers under an advance agreement that the dealers would repurchase the securities in a fixed number of days. The use of these repurchase agreements has increased considerably in recent years.

Such an arrangement is a method available to the Desk for supplying reserves to the banking system; it is used as ar alternative to outright purchases on the open market. A repurchase agreement is, in effect, a loan by the Federal Reserve Bank to private security dealers.

Until December 1971, the interest rate charged by the Desk on funds loaned to the dealers under such agreements was "not less than (1) the discount rate of the Federal Reserve Bank of New York at the time such agreement is entered into, or (2) the average issuing rate on the most recent issue of 3 -month Treasury bills, whichever is the lower." The dealers would not be willing to enter into stuch arrangements if the costs of funds in the market were lower than the cost of additional funds available from the New York Reserve Bank. On December 23, 1971, a majority of the Committee voted to suspend this lower limit through January 11,1972 , the date of the subsequent $\mathrm{FOMC}$ meeting.

Mr. Treiber voted on this action as altemate for Mr. Hayes; Chaiman Burns was absent and not voting.

Mr. Robertson dissented from this action because he believed that the desired injection of funds into the market by the Federal Reserve should be through the outright purchase of U. S. Goverment securities rather than through repur* chase transactions which, in his judgment, actually constituted low-rate loans to securities dealers. He indicated that he was reluctant to increase the profits of dealers by providing them with low-cost Federal Reserve funds merely to avoid temporarily raising the price (lowering the yield) of Treasury securities by purchasing them outright.

At the meeting on January 11, 1972 the Committee ratified the earlier action to suspend the minimum interest charge on RPs. Mr. Robertson dissented from ratification for the same reason he dissented from the action itself. On two subsequent occasions the Com mittee suspended the lower limits on interest rates charged on repurchase agreements. The dates were January 26 through February 15, 1972, and March 7 through March 21, 1972. Mr. Robertson dissented on both occasions, emphasizing that "in his judgment, such agreements actually constituted subsidized loans

1Federal Reserve Bulletin (February 1972), p. 148. to clealers, and he saw no justification for increasing the subsidy by making them at lower and lower rates of intekest.": On the latter occasion Chaiman Bums and $\mathrm{Mr}$. Maisel were absent and not voting and $\mathrm{Mr}$. Brimmer joined Mr. Robertson in dissenting from the action

. . because he felt that excessive reliance was being placed on RP's in open market operations. He was also disturbed about the frequency with which RP's had been made recently at rates below the lower limit that would obtain in the absence of Committee action to suspend the relevant provision of the continuing authonity directive. He thought that since such RP rates were typically below yields on 3-month Treasury bills, their continued use might give the market a misleading impression of the Committee's policy objectives.

On the recommendation of a staff committee appointed to study repurchase agreements, the FOMC amended its continuing authority directive to provide that in the future the interest rate charged on RPs should be determined by competitive bidding unless otherwise expressly anthorized by the Committee. Previously there had been a lower limit on the interest rate on $\mathrm{RPs}$, and, although no upper limit had been specified, in practice the rate charged had not been greater than the Federal Reserve discount rate. The staf commitee felt a competitive bidding procedure would minimize any unintended announcement effects sometimes associated with changes in the RP rate, and it would insure that the costs to dealers of funds obtained through System repurchase agreements were closely related to the costs of funds from altemative sources.

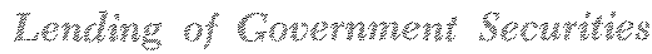

At the March 21 meeting the FOMC reviewed all of its continuing authorizations and directives. This is the customary practice following election of new members from the Federal Reserve Banks to serve on the Committee. In connection with the review, special note was made of the authorization of Reserve Banks to lend U.S. Government Securities held in the System Open Market Account.

This authorization had been added on October 7 , 1969, with the understanding it would be reviewed periodically. At that time,

. . the Manager had advised that the problem of delivery failures in the Government securities market had worsened significantly over the past year, partly because private facilities for lending such securities had become inadequate; that delivery failures were markedly imparing the performance of the market; and that the functioning of the market would be improved if securities held in the System Open Market Account could be lent, for the express purpose of avoiding delivery failures, to Government securities dealers 
doing business with the Federal Reserve Bank of New York and to banks participating in securities clearing arrangements conducted through a Reserve Bank.

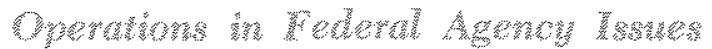

On two occasions last year the FOMC revised its guidelines for the conduct of operations in securities issued by Federal agencies. The Committee had first authorized ontright purchases and sales in agency issues on August 24, 1971. At its meeting on February 15, 1972, the FOMC revised the guideline regarding maturities of eligible isstes so that the maturity of an obligation should be taken as of the time of issuance rather than as of the time of purchase.

The second revision of guidelines on operations in agency issues consisted of an increase in the limit of the holdings of any one issue from 10 percent to 20 percent of the amount outstanding, with the addjtional provision that System holdings of the issues of any one agency could not exceed 10 percent of the total outstanding issues of that agency. This action was taken at the Committee meeting on April 17, 1972.

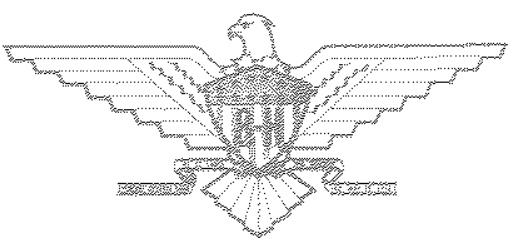

